\title{
A Clinical Study on the Physiotherapy of Congenital Muscular Torticollis
}

\author{
Lee Donggeol, $\mathrm{PT}^{*} \cdot$ Park Kyeongsoon, PT \\ ${ }^{*}$ Dept. of Physical Therapy, Chungnam National University Hospital
}

선천성 사경의 물리치료에 대한 임상적 고찰

\author{
이동걸 ${ }^{*}$. 박경순 \\ "충남대학교병원 물리치료실
}

\begin{abstract}
연구목적 : 본 연구의 목적은 선천성 사경을 가진 22 명의 유아에 대해 임상적 양상과 물리치료 만족 도 및 사경의 요인을 알아보는 것이다.

연구방법 : 설문지를 통해 유아의 성별과 연령분포, 사경의 요인, 사경의 관리, 사경의 물리치료를 조 사하였다.

연구결과 : 1. 환자의 성별 및 연령분포는 남자아이가 9명 $(41 \%)$, 여자아이가 $13(59 \%)$ 이었고, 연령 분포는 $1 \sim 4$ 개월이 5 명(22.7\%), 5 8개월이 6명(27.3\%), 9 12개월이 4명(18.2\%), 그리고 1년 이상은 7 명 $(31.8 \%)$ 이었다.

2. 사경의 정도는 경도가 3 명 $(13.6 \%)$, 중등도 3 명 $(13.6 \%)$, 중증 16 명 $(72.8 \%)$ 이었고, 사경의 분만요 인으로 정상분만 12 명 $(54.5 \%)$, 재왕절개분만 8 명 $(36.4 \%)$, 그리고 둔위분만 2 명 $(9.1 \%)$ 으로 나타났다. 산모의 건강상태에 따른 요인은 매우 양호 7명(31.9\%), 양호 11명(50\%), 약함 3명(13.6\%), 그리고 매우 약함 1 명 $4.5 \%$ ) 이었다. 사경의 요인으로 분석된 가족력, 임신, 분만 사이에는 특별한 관련성은 없었다.

3. 사경 환자가 물리치료를 받는 횟수는 매일 치료 9명(40.9\%), 일주일에 2 3회 12명(54.5\%) 이었 고 물리치료에 대한 만족도는 매우 우수 4명(18.2\%), 우수 15명(68.2\%), 보통 3명(13.6\%)로 나타났 다.

결론 : 이러한 결과를 통해 물리치료가 선천성 사경에 매우 효과적이었다.
\end{abstract}

Key words: 선천성 사경, 물리치료

${ }^{\neq}$Corresponding author:

Lee Donggeol, sopist01@hanmail.net, 011-9484-0937

논문접수일: 2013년 7월 15일 | 수정일: 2013년 8월 10일 | 게재승인일: 2013년 8월 25일 


\section{I . Introduction}

Torticollis was first defined by Tubby. Torticollis is derived from Latin words, which means "twisted neck" Namely, torticollis is the state of having a twisted neck and the functional meaning is that the head is closed to the affected side shoulder and the chin is tilted opposite side due to the rotation and flexion deformation of the neck. Congenital muscular torticollis is usually discovered by the parents at the beginning of birth and it is the third most common congenital musculoskeletal disease after congenital hip dislocation and clubfoot, the prevalence reaches from 0.4 to $1.9 \%$ (Cheng et al, 2001; Binder et al, 1987). Even after a long time, despite reports of congenital muscular torticollis, the cause of muscular torticollis is still unclear (Do, 2006). The most likely hypothesis, however, are displacement of the fetus, birth trauma, vascular accidents, infections, and genetic lesions in the central nervous system (Brooks, 1992; Ling \& Low, 1972; David et al, 1993). Among these, birth trauma due to Breech Presentation or Dystocia is the most frequently reported to account for the disease (Conventry et al, 1960).

Through a great deal of research, different classifications of torticollis have been reported. Torticollis can be classified into three different groups, namely (1) fibromatosis colli, stemamostoid tumor group, the tension of stemocleidomastoid muscle with palpable mass; (2) muscular torticollis which do not have palpable mass but with increased muscular tension (Macdoneld, 1969) and; (3) postural torticollis which does not have a palpable mass nor tension of sternocleidomastoid muscle but, however, has the clinical features of congenital muscular torticollis (Hulbert, 1950). However, many clinicians don't use the three classifications or groups. They divide it into 2 groups, instead. The first group is the group where a palpable mass has been found through a cervical ultrasound while the other group does not have any traces of a palpable mass.

The treatment of torticollis can be divided into conservative treatment which stretches the shortened sternocleido -mastoid muscle, and surgical treatment. Conservative treatment includes a simple observation(Canale et al, 1982), brace, posture and simple catching exercises (Emercy, 1994), gentle manual stretching (Leung \& Leung, 1987), and a vigorous manual manipulation(Hulbert, 1950).

In fact, some of congenital muscular torticollis naturally disappear and are easily corrected manually in its early stages. But initial treatment failure may require surgical treatment so early diagnosis and treatment are also considered very important (Jun et al, 2007). Currently, exercises through physical therapy treatment, manual therapy, therapeutic massages are the most commonly applied in clinical practice. Considering its safety, treatment cost and convenience, physical therapy has its advantages.

This study shows clinical aspects of infants who currently have congenital torticollis, satisfaction in physical therapy, and factors of torticollis.

\section{Method}


subjects

\section{Subjects}

The subjects of this study receive a diagnosis of congenital muscular torticollis from a specialist from April 2011 to July 2011 in the Department of Rehabilitation Medicine, C University Hospital, Daejon. The subjects received physical therapy. The patients included 22 children who are under 12 years old. Who had trauma and those patients whose disease has just been discovered recently were excluded.

\section{Research Methods}

This study is trying to figure out through a questionnaire survey of the child's gender and age distribution, factors of torticollis, management of torticollis and physical therapy in torticollis.

\section{Result}

\section{Gender and age distribution of study}

Table 1. Gender and age distribution

\begin{tabular}{cccc}
\hline Age $($ month $)$ & Male(\%) & Female(\%) & Total(\%) \\
\hline \hline $1 \sim 4$ & $2(9.1)$ & $3(13.6)$ & $5(22.7)$ \\
$5 \sim 8$ & $2(9.1)$ & $4(18.2)$ & $6(27.3)$ \\
$9 \sim 12$ & $1(4.5)$ & $3(13.6)$ & $4(18.2)$ \\
above 1 year & $4(18.2)$ & $3(13.6)$ & $7(31.8)$ \\
Total & $9(41.0)$ & $13(59.0)$ & $22(100)$ \\
\hline
\end{tabular}

Table 2. When the discovery of torticollis

\begin{tabular}{cc}
\hline Month & Number of Patient $(\%)$ \\
\hline \hline Before 1 & $11(50.0)$ \\
Before 2 & $1(4.5)$ \\
Before 3 & $1(4.5)$ \\
Above 3 & $9(41.0)$ \\
\hline
\end{tabular}
and 13 or $59.1 \%$ are girls of the total number of subjects(see Table 1). In terms of age distribution, 5 or $22.7 \%$ are $1-4$ months old, 6 or $27.3 \%$ are 5-8 months old, 4 or $18.2 \%$ are 9-12 months old and 7 or $31.9 \%$ are more than one year old (see Table 1).

2. The timing of discovery of torticollis, types and symptoms

Admitted to our hospital for treatment of infants with congenital torticollis just discovered over a month ago was 11 or $50 \%$, over 2 months ago was 1 or $4.5 \%$, over 3 months ago was 1 or $4.5 \%$ and, 9 or $41 \%$ for more than 3 months(see Table 2).

For the type of torticollis, 18 patients or $81.8 \%$ with torticollis are congenital, 3 or $13.6 \%$ are acquired, 8 or $36.4 \%$ are muscular, 7 or $31.8 \%$ are neurological and 7 or $31.8 \%$ are both muscular and neurological(see Table 3). 
Table 3. Types and symptoms of torticollis

\begin{tabular}{ccccc}
\hline \multicolumn{3}{c}{ Types $(\%)$} & \multicolumn{3}{c}{ Symptoms } \\
\hline \hline Congenital & Acquired & Muscular & Neurological & Both \\
$18(81.8)$ & $3(13.6)$ & $8(36.4)$ & $7(31.8)$ & $7(31.8)$ \\
\hline
\end{tabular}

Table 4. The degree of torticollis

\begin{tabular}{cc}
\hline Severity & Number of Patient $(\%)$ \\
\hline Mild & $3(13.6)$ \\
Moderate & $3(13.6)$ \\
Severe & $16(72.8)$ \\
Total & $22(100)$ \\
\hline
\end{tabular}

\section{The degree of torticollis and factors}

The degree of the severity of pain differs for the infants. 3 or $13.6 \%$ appear to be mild, 3 or $13.6 \%$ are moderate, 16 or $72.8 \%$ are severe(See Table 4 ).

The number of infants who were delivered normally with torticollis is 12 or $54.5 \%$; 8 or 36.4 were delivered through a C-section; and 2 or $9.1 \%$ were Breech Presentation. The mother's health during her pregnancy was also considered. 31.9\% of the mothers reported having an excellent condition, $11 \%$ reported to have good condition, $13.6 \%$ reported fair, and $4.5 \%$ reported a poor condition. Lastly, the percentage of family or genetic factors that may have influenced the existence of the said disease is $100 \%$ (See Table 5).

\section{Management of Torticollis}

The hospitals with Physical Therapy as a treatment for the said disease were selected by 21 or $95.45 \%$ to manage the disease while only 1 or $4.54 \%$ used other methods(See Table 6).

\section{Physical Therapy in torticollis}

The number of patients who received daily treatment through physical therapy were 9 or $41.0 \%$, 12 or $54.5 \%$ received treatment 2-3 times a week and 1 or $4.5 \%$ received treatment 3-4 a month. Only 4 or $18.2 \%$ of the respondents responded on an excellent satisfaction of the treatment, 15 or $68.2 \%$ responded with good, and 3 or 13.6 responded with fair. Majority of the subjects or $90.9 \%$ of them received treatment at home while 9.1\% received the treatment at the hospital(See Table 7). 
Table 5. Factors of torticollis

\begin{tabular}{lcc}
\hline & Classification & Number of Patient $(\%)$ \\
\hline \hline Delivery factor & Normal & $12(54.5)$ \\
& C-section & $8(36.4)$ \\
& Breech & $2(9.1)$ \\
& No answer & \\
\hline Pregnancy factor & Excellent & $7(31.9)$ \\
Mother health & Good & $11(50.0)$ \\
& Fair & $3(13.6)$ \\
& Poor & $1(4.5)$ \\
\hline Family factor & & 0 \\
& Yes & $22(100)$ \\
\hline
\end{tabular}

Table 6. Management of torticollis

\begin{tabular}{cc}
\hline Management & Number of Patient $(\%)$ \\
\hline \hline Physical Therapy & $21(95.45)$ \\
Drug or Surgery & $0(0)$ \\
above of All & $1(4.54)$ \\
Total & $22(100)$ \\
\hline
\end{tabular}

Table 7. Physical therapy on torticollis

\begin{tabular}{ccc}
\hline Physical Therapy(P.T) & Tx duration(day) & Number of Patient(\%) \\
\hline \hline Frequency of P.T & Every day & $9(40.9)$ \\
& Week of 2 3 & $12(54.5)$ \\
Effect of P.T & Month of 3 4 & $1(4.5)$ \\
& Excellent & $4(18.2)$ \\
& Good & $15(68.2)$ \\
& Fair & $3(13.6)$ \\
Home of P.T & Poor & $0(0)$ \\
& Yes & $20(90.9)$ \\
& No & $2(9.1)$ \\
\hline
\end{tabular}

\section{Discussion}

Torticollis is the state of having a twisted neck. Properly defined, torticollis is the state where the head is tilted to the one side due to the shortened sternocleidomastoid muscle which pulls the mastoid process to the sternoclavicular joint in the same side(Howell, 1929).

The diagnosis of congenital muscular torticollis typically relies primarily on clinical symptoms and palpation. In some cases, computer tomography, radiology and 
muscle biopsy can also be diagnosed through an ultrasound. In the case of congenital muscular torticollis, the head tilted to the affected side and chin tilted opposite side, represents a palpable mass due to fibrosised sternocleidomastoid muscle and it is often found in children between 6-8 weeks old when the flexion posture disappears rather than immediately after birth(Lidge et al, 1957). The causes of variation is muscle shortening due to fibrosis of the strnocleidomastoid muscle, but it uncertain.

Ratios in this study shows that 9 boys $(41.0 \%)$ and 13 girls or $(59.0 \%)$ are affected. This shows that more girls are affected than the boys. Converty et al (1960) also reported that the prevalence in girls is higher than in boys. However, Altenberg and Chandler(1994) reported that there were no differences in the sex ratio. In this study, $31.9 \%$ of the infants were over a year old, while 6 were 5 to 8 months old, 5 were 1-4 months old and 4 were 9-12 months old.

The discovery of torticollis in this study shows that 11 (50\%) of patients have just discovered the said disease over a month ago, $1(4.5 \%)$ discovered the disease over 2 months ago, 1 (4.5\%) over 3 months ago, and 9 (41.0\%) of the patients discovered the disease more than 3 months ago. There are no reliable factors for identifying the said disease. But, as a viable hypothesis, Dystocia and Breech Presentation have high frequency of occurrence of torticollis and it is reported that $30-60 \%$ of congenital torticollis patients have a history of Breech Presentation(Conventry et al, 1960; Lidge et al, 1957), but there is no basis at all to divided the factors of torticollis by the type of birth because in this study, majority of the patients or $54.5 \%$ of the patients who went through a normal delivery had the said disease; $36.4 \%$ were delivered in a C-sectin. Thompson et al(1986) insisted that there are genetic elements that influence the disease. In this study, however, there are no traces of the disease in the family's history.

The existing treatment policy was determined primarily by age. Some authors claim that surgery is needed after a few weeks from birth but symptoms before the age of one are usually gone through conservative therapy such as braces, exercises and massages, and have been reported with satisfactory results(Coventry et al, 1960).

In addition, the treatment of torticollis involves several methods such as a simple observation, aid, home care, manual traction, and a variety of surgical techniques(Shim et al, 2004), but it has been reported that manual stretching conducted by a skilled therapist with a clear plan showed a high success rate (Cheng et al, 2001).

In this study, 21 or $95.45 \%$ of the patients compose those who received physical therapy and 19 or $86.4 \%$ of those who received physical therapy were satisfied with their caregivers. Also, 20 or $90.9 \%$ of the patients receive physical therapy at home. Physical therapy in the treatment of infants with the said disease shows a lot of satisfaction. Therefore, it is important to accurately and continuously give physical therapy to patients suffering from torticollis.

\section{Conclusion}


The following conclusion was obtained by analyzing the general characteristics, timing of discovery, types and symptoms, degree and physical therapy of the 22 infants with congenital torticollis admitted to our hospital.

1. Gender and age distribution. Girls make up the majority of the patients with $59 \%$ while boys are $41 \%$ of the patients. Majority of the patients were more than one year old (31.8\%), followed by eight months or less (27.3\%), less than 4 months (22.7\%) and less than 4 patients (18.2\%).

2. In terms of the degree of severity of pain, majority of the patients (72.8\%) reported severe pain, and the rest of the patients were divided between mild and moderate pain. Meanwhile, normal birth delivery accounts for majority or $54.5 \%$ of the patients who are suffering the said disease, $36.4 \%$ through a $\mathrm{C}$-section and 9.1\% through breech. Lastly, there are no genetic factors. This part of the result shows that Birth factors, pregnancy factors, and family factors are not associated with the said disease.

3. The results of the physical therapy with torticollis. 12 or $54.5 \%$ of the subjects took the physical therapy 2-3 times a week while 9 or $40.9 \%$ of them took the therapy daily. In terms of satisfaction, 19 or $86.4 \%$ of the subjects were satisfied with the effects or the results of the therapy.

\section{References}

Altenberg A, Chandler FA(1994). Congenital muscular torticollis. JAMA, 125, 476-483.

Binder H, Eng GD, Gaiser JF, et al(1987). Congenital muscular torticollis: results of conservative management with long-term follow-up in 85 cases. Arch Phys Med Rehabil, 68(4), 222-225.

Canale ST, Griffin DW, Hubbard CN(1982). Congenital muscular torticollis. A long-term follow-up. J Bone Joint Surg Am, 64(6), 810-816. Cheng JC, Wong MW, Tang SP, et al(2001). Clinical determinants of the outcome of manual stretching in the treatment of congenital muscular torticollis in infants. A prospective study of eight hundred and twenty-one cases. J Bone and Joint Surg Am, 83(5), 679-687.

Conventry MB, Harris LE, Bianco AJ, et al(1960). Congenital muscular torticollis(wryneck). Postgraduate Med, 28, 383-392.

David JR, Wenger DR, Mubarak SJ(1993). Congenital muscular torticollis: Sequela of intra-uterine or perinatal compartment syndrome. J Pediatr Orthop, 13(2), 141-147.

Do TT(2006). Congenital muscular torticollis: current concepts and review of treatment. Curr Opin Pediatr, 18(1), 26-29.

Emery C(1994). The determinants of treatment duration for congenital muscular torticollis. Phys Ther, 74(10), 921-929.

Brooks B(1992). Pathologic changes in muscle as a result of disturbance of circulation. Arch Surg, 5, 188-216. 
Howell BW(1929). The treatment of torticollis. Br Med J, 2, 714-716.

Hulbert KF(1950). Congenital torticollis. J Bone Joint Surg Br, 32(B), 50-59.

Jun JE, Ryu HK, Shim JW(2007). Clinical features of congenital muscular torticollis. Korean J Pediatr, 50(3), 241-247.

Leung YK, Leung PC(1987). The efficacy of manipulative treatment for sternomastoid tumors. J Bone Joint Surg Br, 69(3), 473-478.

Lidge RT, Bechtol RC, Lambert CN(1957). Congenital muscular torticollis; Etiology and pathology. J Bone joint Surg Am, 39(A),
1165-1182.

Ling CM, Low YS(1972). Sternomastoid tumor and muscular torticollis. Clin Orthop Relat Res, 86, 144-150.

Macdoneld C(1969). Sternomastoid tumor and muscular torticollis. J Bone Joint Surg, 51(3), 432-443.

Shim JS, Noh KC, Park SJ(2004). Treatment of congenital muscular torticollis in patients older than 8 years. J Pediatr Orthop, 24(6), 683-688.

Tompson F, McManus S, Colville J(1986). Familial Congenital muscular torticollis: Case report and review of the literature, 202, 193-196. 